\title{
The Effect Of Performance Allowances On Motivation, Employees' Work Achievement and Organizational Performance in Government Offices
}

\author{
Muhammad Mudhofar* \\ Accounting, Economy, Sekolah Tinggi Ilmu Ekonomi Widya Gama Lumajang, Indonesia
}

Received: 26 February 2021; Reviewed: 07 March 2021; Accepted: 23 March 2021

*Coresponding Email: muhammadmudhofar19@gmail.com

\begin{abstract}
This study aims to analyze the effect of performance allowance as a determinant of motivation, employees' work achievement and organizational performance in the Ministry of Religion's Office Lumajang City. This determining variable is important for public organizations to improve services and fulfill bureaucratic reform. This quantitative research uses Structural Equation Modeling (SEM) data analysis tools with AMOS software. The research population was 153 Ministry of Religion employees. The modeling results show the GFI index value of 0.906; CFI 0.969; and RMSEA 0.040. Hypothesis testing shows the insignificant direct effect between performance allowance and motivation, employees' work achievement and organizational performance. Factors that determine the improvement in performance of public organizations are directly and significantly affected by by work achievement. Work achievement contributes the most to organizational performance. High work achievement requires a number of supporting factors, namely performance allowance and motivation. This research provides a practical contribution in policy making for government organizations regarding efforts to improve organizational performance through work achievement. Performance allowance and motivation is an important element to directly improve employee work achievement as a medium to improve organizational performance. The originality value of this research is very good because it was first carried out on the object of a public organization that has just applied compensation payments for the State Civil Apparatus in the form of performance allowances by testing and measuring the implications of the compensation factor as a determinant of organizational performance.
\end{abstract}

Keywords: Performance Allowance; Motivation; Work Achievement; Organizational Performance.

How to Cite: Mudhofar, M., (2021). Performance Allowance Motivation Employees' Work Achievement And Organizational Performance at Among Government Employees. Jurnal Administrasi Publik (Public Administration Journal). 11 (1): 101-110 


\section{INTRODUCTION}

Performance is a structure in determining the efforts to achieve high levels of productivity in an organization. Many factors influence the performance of public organizations that include performance allowances, work environment, motivation, and employee's performance. Studies have shownthat work environment, manager attitude, organizational culture, personal problem and work context are influential of employee performance (Saeed et al., 2013). In a public service organization, the performance of employees who perform their duties professionally according to the spirit of bureaucratic service paradigm becomes a benchmark in achieving organizational performance goals. This paradigm is in line with Denhardt and Denhardt (2007) who contend that government cannot be run like a business but it must be run like a democracy

The Ministry of Religious Affairs of Lumajang Office has demanded the employees to optimally perform their tasks and functions. Performance evaluation on public organizations is essential as a foundation for improving the quality of public services. Performance evaluation is used to assess the performance of a public organization in providing services to the public, because basically the orientation of public organization is to prioritize public service (public service oriented). It is also used as a tool to evaluate performance in the past period as a basis for the preparation of the next strategy. In the context of public organization performance, it is a measure of achievement or outcome in managing and running an organization related to many aspects. Employee's performance assessment is important because it is useful as a reference to improve the organizationfor better performance in the future. The assessment is conducted towhich areimprove government performance, resource allocation and decision-making, realize the accountability of public organizations and explore differences comprehensively (Andrews et al., 2010).

The Ministry of Religious Affairs of the Republic of Indonesia had introduced the provision of performance in 2014to improve work achievement and organizational performance of employees. Performance allowance is a part of compensation for the State Civil servants for the job performance they have done.The purpose of this allowance isnot only to improve employees' performance and the performance of the organizationbut alsoto be a motivation for state civil servant. Thus, it is expected to have positive impact on the performance or work achievement. The granting of performance allowances to employees is classified into several grades based on their tasks and functions. The grade determines the amount of performance allowances received by each employee. Performance allowances are given to civil servants every month in addition to their regular salary. The amount of payment of performance allowances is calculated based on work attendance and individual performance achievement. The determination of class of positions is stated in the Regulation of the Minister of Religion Nomor 51 of 2014. It determines the amount of a fair and decent performance allowances in line with the scope and impact of employment, authority, employment relationship, difficulties and job responsibilities. Providing performance allowances can increase work productivity and the quality of organizational performance at a good level (Munawir, 2015).

Performance allowance is an additional benefit from the organization to the employees as a consequence of their responsibility. Simanjorang and Tumbuan (2016) contend that performance allowance is an employee welfare program comes from the organization. Hasniati (2017) shows that the performance 
allowance influences the employees' work achievement. It becomes a part of compensation given by the organization. That is, the higher the performance allowance, the higher is the quality of work quality of the employees' (Simanjorang and Tumbuan, 2016).

Other factors that can support the increased productivity of human resources are efforts to increase the motivation of adequate work, such as the fulfillment of needs both external (primary needs, food, clothing and shelter as well as adequate environment) and internal needs (employees' desire to put themself in a satisfactory career position). Al-Madi et al. (2017) stated that motivation has the dimension of persistence of a person to maintain performance that benefits the organization. Motivation is the provision of the power of movement that creates the enthusiasm of one's work so that they will cooperate, work effectively and integrate with all their efforts to achieve satisfaction. Motivation can also make significant contribution to the success of individuals and organizations in achieving its goals. Manzoor (2012) finds significant relationship between employee motivation and organizational effectiveness. But intrinsic motivation had no significant effect on performance (Hayati and Caniago, 2012). Employees with high work motivation have a positive impact on employee work achievement and the quality of organizational performance (Darmanto and Harahap, 2015).

In globalizationera, it is anundenieable fact that the basic motivation for most employees in any organization is to earn for living. It means that employees use knowledge, skills, energy and part of time to work on any organization, but on the other hand the employees are expected to receive certain rewards. Yamoah (2013) states that good compensation is a motivating strategy for employees to increase their work productivity.The improvement of external and internal motivation can encourage employees to work more productive. Increasingof work motivation also needs to be given in the form of coaching to encourage enthusiasm and passion of employees, improve morale, improve employees' productivity, maintain loyalty, improve discipline and improve the atmosphere and good working relationships among civil servants. Motivation can influence the result of the employees' performance (Zameer et al., 2014; Shahzadi et al., 2014). Motivated employees can positively influence the growth, welfare, and productivity of the organization (Manzoor, 2012).

Improving the quality of organizational performance is also determined by employees' work achievement. Work achievement is a work achieved by someone in carrying out the tasks assigned to him based on skill, experience and sincerity and timeliness. Job performance is a result of work done by employees from time to time. Job performance is a comparison between a person's appearance with the expected results through the implementation of his work in accordance with procedures and responsibilities determined by the organization (Borman and Motowidlo, 1997 in Sungkono and Dewi 2017). Work achievement of the employees is very important element in an organization. Evaluation of work achievement is the process where the organization evaluates or judges the achievement of its employees.Work achievement evaluation could be in the form of work quantity, quality, ability, initiative, skill, attitude and attendance (Heidjrachman dan Husnan, 2000). The employee performance governance and good work achievement are able to deliver optimal organizational performance (Syafrida and Tarigan, 2013).

This research is aimed to examinethe factors that determine performance allowance. These include motivation, work achievement of employees and 
organizational performance at Office of the Ministry of Religious Affairs Lumajang City. Research on public organizations is interesting because of performance measurement of public organizations is more difficult to achieve than private organizations. Denhardt and Denhardt (2007) state that public organizations should prioritize the interests of the community in service. Public sector organization performance measurement is more difficult toachieve and has some constraints than private organizations

The paper is organized as follows. Section one introduction and literature review. The section two provides the research methods. The third section provides the results and discussion. Final section concludes the paper.

RESEARCH METHODS
This type of research is quantitative methods with the category of associative research. Sugiyono (2014) states that associative research aims to test whether there is a correlation between variables or not. The data of the study are collected using close-ended questionnaires. The data analysis tool to test hypotheses is the Structural Equation Model (SEM) with AMOS software version 20. The population areemployees holding structural position, and holding certain and general functional levelin the Ministry of Religious Affairs of Lumajang Office which there are 153 employees (as of December 2018). All employees are given the questionnaires. Yet, 140 or $91.3 \%$ are received and usable.Table 1 provides summary of the variables and indicators.

Table 1.Researchvariables and Indicators

\begin{tabular}{ll}
\hline Variable & Indicators \\
\hline Performance Allowances & Values and position classes \\
(Hariyati et al, 2015) & Allowance \\
& Intensive \\
\hline Work Motivation & Amenities \\
(Rivai, 2004) & Physiological \\
& Appreciation \\
\hline Work Achievement & Social \\
(Heidjrachman dan Husnan, 200o) & Self-actualization \\
& Work quality \\
& Initiative \\
\hline Organizational Performance & Discipline \\
(Dwiyanto, 20o8) & Knowledge \\
& Productivity \\
& Quality of service \\
\hline
\end{tabular}

\section{RESULTS AND DISCUSSION}

The data show that the majority of respondents are male ( 95 or $67.9 \%$ ). About half of them are between 41 and 50 years old (64 or 47\%). The majority of respondents are married (134 or 96\%). About half of them are holding tertiary education (64 or 47\%). Most of respondents have been working for more than 20 years ( 47 or $34 \%$ ). From sixtypes of job classification, the functional position is having the largest member of employees (39 people or $28 \%$ ).

Table 2 presents the results of validity and reliability tests. As can be seen, loading factors on the entire indicators range from 0.465 to 0.813 which are higher than the cutt-off point of 0.50 . These indicate good construct validity. Composite reliability coefficients are between 0.729 and 0.804 which are higher than the cutt-off point of 0.700 and average variance extracted 
(AVE) range is $0.408-0.500$. These imply that there is a good construct reliability

Table 2.Validity and Construct Reliability Analysis Results

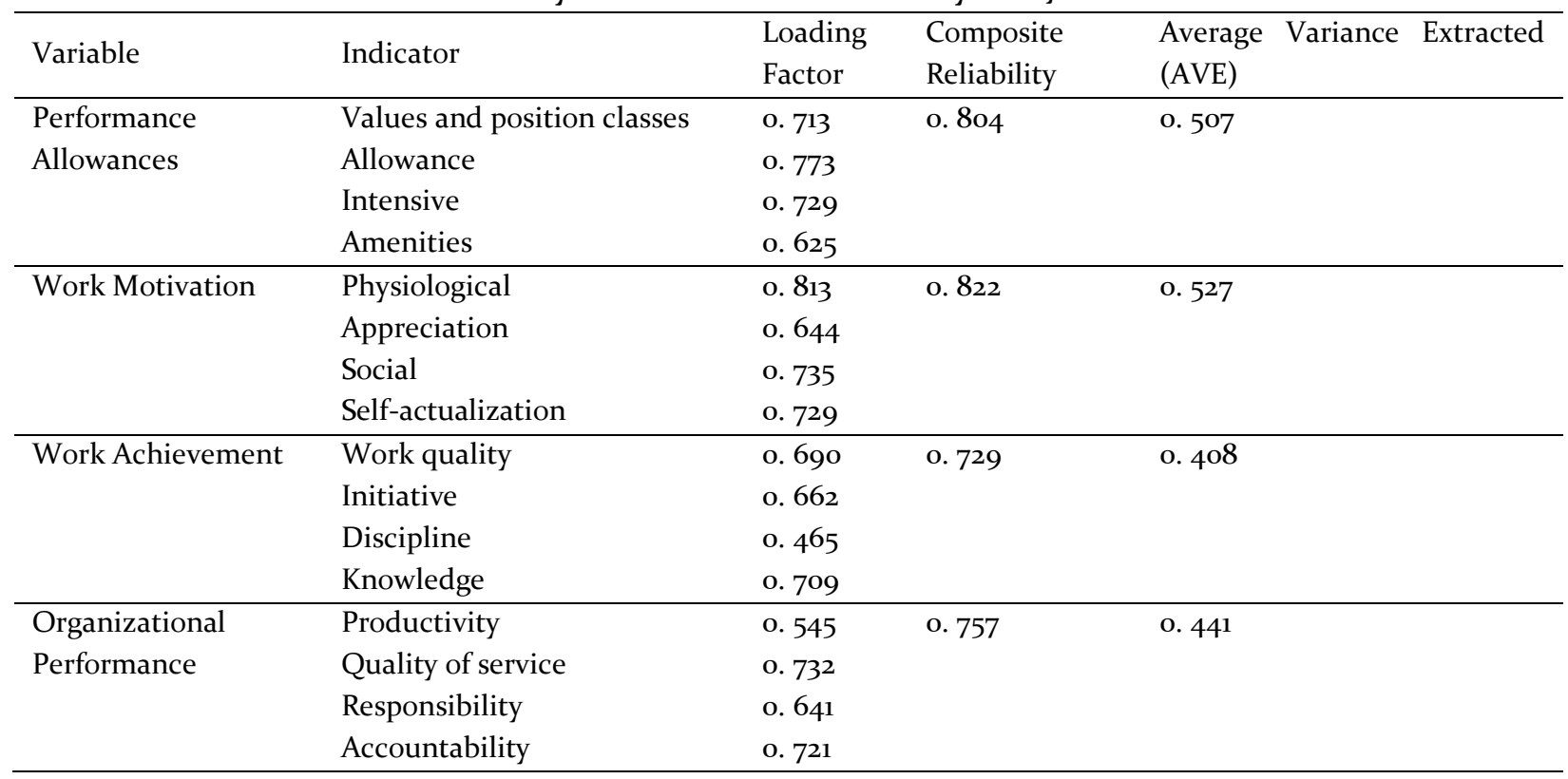

Results of test on discriminant validity are shown in Table 3. Discriminant validityis measured by comparing the root of AVE from a construct with correlation coefficient on other variables. For instance, on the performance allowance the root number of AVE is 0.712 , which is greater than the correlation coefficient on the other variables with the range of 0.418 to 0.557 . Thus, the construct has gooddiscriminant validity as well as the analysis results toward the other variables. Construct reliability is assessed from the discriminant validity.

Table 3. Discriminant Validity Analysis Result

\begin{tabular}{lllll}
\hline Variable & $\begin{array}{l}\text { Performance } \\
\text { Allowances }\end{array}$ & $\begin{array}{l}\text { Work } \\
\text { Motivation }\end{array}$ & $\begin{array}{l}\text { Work } \\
\text { Achievement }\end{array}$ & $\begin{array}{l}\text { Organiaational } \\
\text { Performance }\end{array}$ \\
\hline Performance Allowances & $(\mathrm{o.712})$ & & & \\
Work Motivation & 0.418 & $(0.733)$ & & \\
Work Achievement & 0.546 & 0.644 & $(0.639)$ & $(0.664)$ \\
Organizational Performance & 0.557 & 0.497 & 0.706 & $(0.606$ \\
\hline
\end{tabular}

The hypotheses test resultsare presented in Figure 1. As shown, thefit model on the analysis is good. The Chisquare is insignificant $(\chi 2=120.321$; $\mathrm{p}=0.063$ ). It indicates the covariance matrix on the data is the same as the covariance matrix on the models. The other fit model indexes are met. GFI and AGFI indexesare at
0.906 and 0.869 , respectively. Both are in a favorable state and marginal since they are in the range of 0.80-0.90 (Hair et al., 2010). CFI and TLI index as are at 0.969 and 0.962 . It implies that both indexes are in a good state since they are beyond 0.95 value. On the other hand, RMSEA is at 0.040 and in a good state since the value is less than 0.08 . 


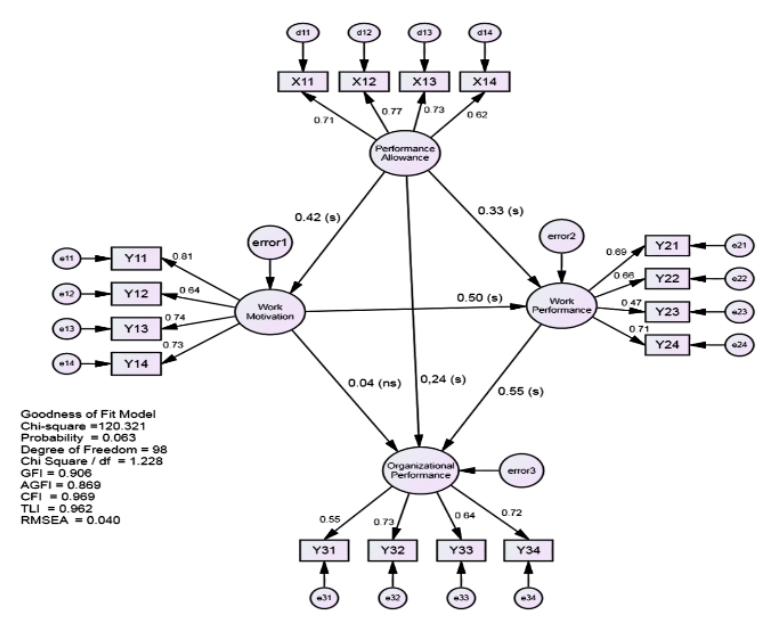

Path coefficient test results are shown performance allowance on work motivation is significant $\quad(\beta=0.418$; $\mathrm{p}<0.001)$. Work motivation has stronger influence on work achievement $(\beta=0.504$; $\mathrm{p}<0.001$ ) rather than on performance allowance $\quad(\beta=0.335 ; \quad p=0.002)$. Organization performance is significantly affected by two factors, the performance allowance $(\beta=0.240 ; p=0.048)$ and work achievement $(\beta=0.546 ; p=0.003)$. The organization performance could not be directly explained by work motivation $(\beta=0.044 ; p=0.736)$.

in Table 4. It indicates that the effect of

Table 4. Path Coefficient Test Results

\begin{tabular}{lllll}
\hline Correlation & $\begin{array}{l}\text { Path } \\
\text { Coefficient }\end{array}$ & C. R & P & Status \\
\hline Performance Allowances $\rightarrow$ WorkMotivation & 0.418 & 3.916 & 0.000 & Significant \\
Performance Allowances $\rightarrow$ Work Achievement & 0.335 & 3.030 & 0.002 & Significant \\
Work Motivation $\rightarrow$ Work Achievement & 0.504 & 4.373 & 0.000 & Significant \\
Performance Allowances $\rightarrow$ Organizational Performance & 0.240 & 1.980 & 0.048 & Significant \\
Work Motivation $\rightarrow$ Organizational Performance & 0.044 & 0.337 & 0.736 & Not Significant \\
Work Achievement $\rightarrow$ Organizational Performance & 0.546 & 3.002 & 0.003 & Significant \\
\hline
\end{tabular}

Table 4 shows significant direct influence of performance allowance on the employees' performance. Higher employees' work achievementis mainly from a group of employees who find themselves sufficient in performance allowance they receive. Performance allowance has the same meaning as reward or compensation that is often called as appreciation. It may be elaborated as a form of acknowledgement that is given to an employee as a tribute or contribution to which they give to the organization. Performance allowance is used in an organization as a means to increase employees' quality.

Performance allowance significantly affects all variables. Substantially, performance allowance is defined by allowance indicator since the biggest loading factor is on this indicator. High perception against performance allowance is reflected by the high perceptions on the allowance. Based on the amount of loading factor of the four performance allowance indicators and there are three main indicators, namely the amount of allowance, the amount of incentive, the occupational value and class. In other words, the amount of employees' perceptions against performance allowance would be reflected by the negative or positive responses on the three indicators.

Based on the descriptive analysis results, there were two relatively high indicators according to the average ratio between them, the amount of allowance and occupational value and class. Both indicators are high and have become one of the main indicators as a performance allowance measurement. This is because the employees believe that the performance allowance given in the MRA is higher compared to other government institutions. The performance allowance could be obtained every month similar to monthly salary. It is also considered to be 
valuable and could be beneficial to the retired employees. The variety of performance allowance is a form of equality since every duty given is not the same.

The amount of incentive and facility provided to the employees is low. The MRA needs a system that is transparent and provides equity in terms of incentive as well as budget additional. The distribution of facility corresponding to the occupations can be improved by optimizing any plan that could support labor activity. In MRA, performance allowance is a form of compensation given by the Government to civilservantson any completed activity and has been applied since 2014. Although this performance allowance is given periodically of $65 \%$ of the entire allocation, this performance allowance is expected to become the Government's effort to raise the civilservants satisfaction and their performance. Giving performance allowance correctly may directly influence the employee motivation (Rokhimakhumullah, 2016). A proper allowance will influence the employees' professionalism, prosperity and will affect public services (Nugroho et al., 2018). Performance allowance administration should consider the workload aspect and the employees' quality. In other words there should be a significant difference between employees with high productivity and low productivity, or else it will cause the employees' performance to become less optimal (Prendergast, 2002).

Human resource management and effective organization are also crucial in improving employees' performance (Kusumastuti, 2015). An organization financial improvement should influence the allowance given to the employees. The adjustment in improving allowance is closely related to selective requirements of performance allowance allocation system. It is reflected between the submission requirements, the result of management control system and the organization internal control mechanism, which will then become a part of organization report to external parties.The submission requirements will induce the change in management control system that underlies the improved organization accountability (Sopp and Baumuller, 2012). After an organization carries out the allocation of performance allowance, there should be a special committee of performance allowance which is to provide input and analysis related to its culture, standard and financial potential that exist in it (Silingiene et al., 2015).

There are four indicators that significantly contribute in measuring work achievement. Substantially, initiative indicator elaborates work achievement since the greatest loading factor is on this indicator. The great work achievementis reflected in the elevated employees' initiative. Based on the amount of loading factor of the four work achievement indicators, there are two main indicators, the initiative level and work quality. In other words, employees' performance level is reflected in the level of response on both indicators. The descriptive analysis results, show on average that there are two relatively high indicators, the initiative level and discipline. But, the work quality and the knowledge are quite low. The employees' initiative level and work quality are the components that bolster the work achievement in the in the Ministry of Religion's Office Lumajang City.

Work motivation and work achievement are significantly relatedto employees with higher motivation and they will tend to form better work achievement. Motivation is a willingness to do a big effort in order to achieve some targets that have been set and arranged (Robbins and Mary, 2005). In this case, good leader is important. A leader needs to understand their employees' behavior in order to motivate or influence them. To motivate employees,a leader should be a good communicator, be a good listener, a good organizer, as well as using a good approach in solving problems and selfless. Motivation 
could significantly influence the employees' performance (Zameer et al., 2014). Overall employees' motivation in an organization affects the employees' performance.

Physiologic indicator mainly forms work motivation, as it has the biggest loading factor. High motivation is reflected by the elevated fulfillment of the employees' physiological needs such as the amount of salaryor the convenience to receive a reward. The descriptive analysis shows that there are two relatively high indicators, the physiologic and social. Selfesteem and self-actualization are low.

The study finds that work motivation is not directly related to the organization performance. Employees' motivation will influence their performance and in the end will impact on organization performance. Yet, the current study does not find significant effect of work motivation on organization performance. Shahzadi et al., (2014) reports that there are significant and positive motivations parallel to employees' performance. Manzoor (2012) claims that there is a connection between employees' motivation and organization's effectiveness.

Work achievement shows a significant relationship with organizational performance. Organizational performance will increase if the employee's work performance is good. Substantially, work performance is based on indicators of knowledge and quality of work, because the biggest burden factor is on these indicators. Knowledge determines the value of work performance. Low-discipline discipline so that it needs to be improved in the next future. Some things that can be done to improve employee discipline are determining a clear and appropriate job description.

Organizational performance is substantially in indicator by indicator of services provided to society. The productivity indicator has a relatively low factor loading value compared to the other three indicators. The way that can be done to increase employee productivity is to include technical guidance, training and the like on a rotating basis and develop the results. The Ministry of Religion of Lumajang City will continue to compete among public organizations in realizing its vision and mission through various strategic plans. Thus it is inevitable to continue to innovate and be creative in realizing advanced and professional organizational performance.

\section{CONCLUSION}

It finds that work achievementhas the most significant contribution on organization performance. The improvement of organization performance is highly determined by the level of work achievement. Work achievementis supported byperformance allowance and work motivation. Productivity and responsibility indicator contribute the most in assessing the organization performance. The high level of productivity and response time represents the organization performance. Initiative and knowledge indicators are highly contributed in assessing work achievement. The high level of employee work achievementis highly depicted in the elevated employees' initiative and proficiency.

The impact of providing performance allowance to improve organizational performance can be direct and indirect in the form of the effect of maintaining motivation and better workachievement. With another meaning performance allowancethat are far from employee expectations will initially reduce motivation and work achievementbefore impacting on organizational performance.Performance allowance and work motivation are significant inelevatingwork achievement. They also have significant indirect role to bolster the organization performance. Work achievement, supported by motivationis the key to increase organization performance. 


\section{BIBLIOGRAPHY}

Al-Madi, F.N.,Assal, H., Shrafat, F., and Zeglat, D. 2017. The Impact of Employee Motivation on Organizational Commitment. European Journal of Business and Management. Vol. 9(15): 134-145.

Andrews, R., Boyne, G.A., Moon, M.J., and Walker, R.M. (2010). Assessing Organizational Performance:Exploring Differences Between Internal and External Measures. International Public Management Journal. Vol. 13(2): 105129. DOI: $10.1080 / 10967491003766533$.

Darmanto and Harahap, R.H. (2015). Pengaruh Motivasi dan Disiplin Kerja Terhadap Kinerja Pegawai Sumber Daya Alam Sumatera Utara. Jurnal Ilmu Administrasi Publik. Vol. 3 (1); 120.

Denhardt, J.V., and Denhardt, R.B. (2007). The New Public Service : Serving Not Steering. New York: M. E. Sharpe.

Dwiyanto, A. (2008). Reformasi Birokrasi Publik di Indonesia. Yogyakarta: BPFE UGM.

Hair, J.F., Anderson, R.E., Tatham, R.L. and Black, W.C. (2010). Multivariate Data Analysis. $7^{\text {th }}$ edition. New Jersey: Person Education Inc.

Hariyati, R., Kiyai, B., and Ruru, J.M. (2015). The Effect of District Performance Allowance on Public Services (A Case Study at Health Department of Ternate, Maluku Province, Indonesia). Jurnal Administrasi Publik.. 4(32): 1-9.

Hasniati, (2017). The Effect of Performance Allowance on Public Servant Performance at Agricultural Extension College Gowa. Jurnal STIE AMKOP. Makasar. 4 (1): 362-372.

Hayati, K., and Caniago, I. (2012). Islamic Work Ethic: The Role of Intrinsic Motivation, Job Satisfaction, Organizational Commitment And Job Performance. American Journal of Industrial and Business Management. Vol. 5(3): 1102-1106. DOI: 10.1016/j.sbspro. 2012.11.122

Heidjrachmanand, R and Husnan, S. (2000). Personnel Management. Yogyakarta: BPFE UGM.

Kusumastuti, D. (2015). Performance Appraisal and Remuneration Model For Lecturers at a University en Route For World Class: A Study at a Faculty of Business and Management. International Journal of Economics, Commerce and Management. Vol. 3 (5): 381-400.

Manzoor, Q.A. (2012). Impact of Employees Motivation on Organizational Effectiveness. Journal Business Management and Strategy. Vol. 3(1): 1-12. DOI: 10.5296/ bms.v3i1.904.

Munawir, A.K. (2015). Pengaruh Pemberian Kompensasi Terhadap Produktivitas Kerja Karyawan Pada PT. Victorindo Alam Lestari Kabupaten Padang Lawas. Jurnal Ilmu Administrasi Publik. Vol. 2 (3); 133-144.
Prendergast, C. (2002). The Tenous Trade-off Between Risk and Incentives. Journal of Public Economy. Vol.110(5): 1071-1102. DOI: 10.3386/w7815.

Nugroho, S.H., Gunawan, K. and Madhakomala, R. (2018). Policy Evaluation of Performances Allowance using System Dynamics Approach: Case Study of Indonesia Navy. International Journal of Scientific Research and Management (IJSRM). Vol. 6 (3): 10-18. DOI:https://doi.org/10.18535/ijsrm/v6i3.s2

Regulaiton of the Ministry of Religious Affair of Indonesia No. 51 year 2014 concerning The Value and Class of Structural and Functional Position in the Ministry of Religion.

Regulation of the Ministry of Religious Affair of Indonesia No. 49 year 2014 Concerning the Giving, Adding and Reducing Performance Allowances for Civil Servants in the Ministry of Religion.

Rivai, V. (2004). Manajemen Sumber Daya Manusia Untuk Perusahaan. Jakarta: Raja Grafindo Persada.

Robbins, S.P., and Mary, C. (2005). Management. New Jersey: Prentice Hall Inc.

Rokhimakhumullah, D. N. K. (2016). The Effect of Performance Measurement System and Remuneration to Employee Performance With Organizational Culture As a Moderating Variable. Journal of Innovation in Business and Economics. 1(2): 93-100. DOI: $10.22219 / J I B E$.

Saeed, R., Mussawar,S., Lodhi, R.N., Iqbal, A.,Nayab, H.H.,and Yaseen, S. (2013). Factors Affecting the Performance of Employees at work Place in the Banking Sector of Pakistan. Middle-East Journal of Scientific Research. Vol. 17 (9):1200-1208. DOI: 10.5829/idosi.mejsr. 2013.17.09.12256.

Shahzadi, I., Javed, A., Pirzada, S.S., Nasreen, S., and Khanam, F. (2014). Impact of employee motivation on employee performance. European Journal of Business and Management. Vol. 6(23): 159-166.

Silingiene, V., Stukaite, D., and Radvila, G. (2015). The Remuneration Determinants of Chief Executive Officers: A Theoretical Approach. Procedia-Social and Behavioral Sciences: 848854. DOI: 10.1016/j.sbspro. 2015.11.494.

Simanjorang, M.I., and Tumbuan, W.J.F.A. (2016). The Influence of Performance Allowance and Employee Development To Employee Performance In State Assets and Service Office Manado. Jurnal EMBA. Vol. 4(1): 1561165.

Sopp, K., and Baumüller, J. (2012). Remuneration Systems of The Management Board and Corporate Governance Reporting-Evidence from Austria. Procedia Economics and 
Muhammad Mudhofar, Performance Allowance Motivation Employees' Work Achievement and

Finance. Vol. 2(3): 35-44. DOI: 10.1016/ S2212-5671(12)00062-7.

Sugiyono. (2014). Metode Penelitian Administrasi, Cetakan ke 22, Bandung: Alfabeta

Sungkono, S.W., and Dewi, I.M. (2017). Pengaruh Prestasi Kerja, Loyalitas Kerja Terhadap Promosi Jabatan di PT. Bali Pawiwahan Coco Group. E-Jurnal Manajemen Unud. Vol. 6(4): 1991-2017.

Syafrida, A and Tarigan, U. (2013). Pengaruh Motivasi Terhadap Prestasi Kerja Pegawai Pada Biro Perekonomian Sekretariat Daerah Provinsi Sumatera Utara. Jurnal Ilmu Administrasi Publik. Vol. 3 (1); 45-57.
Yamoah, E.E. (2013). Relationship Between Compensation and Employee Productivity. Singaporean Journal of Business Economics and Management Studies. Vol. 2(1): 110-114. DOI: $10.12816 / 0003845$.

Zameer, H., Ali, S., Nisar, W., and Amir, M. (2014). The Impact of The Motivation on The Employee's Performance in Beverage Industry of Pakistan. International Journal of Academic Research in Accounting, Finance and Management Sciences. Vol. 4(1): 293-298. DOI: $10.6007 /$ IJARAFMS/v4-i 